УДК 616.314-76-77:378.6

DOI

(СП. А. Гасюк ${ }^{1}$, Д. М. Король ${ }^{2}$, С. О. Росоловська ${ }^{1}$, Л. С. Коробейніков ${ }^{2}$, В. Б. Радчук ${ }^{1}$, Р. В. Козак ${ }^{2}$

ДВН3 «Тернопільський державний медичний університет

імені І. Я. Горбачевського» ${ }^{1}$

ВДН3 України «Українська медична стоматологічна академія», м. Полтава²

\title{
Методологія впровадження навчального посібника «Технологічні аспекти виготовлення ортопедичних конструкцій» у навчальний процес із вибіркової дисципліни
}

Резюме. У статті викладено методику проектування та розробки типової програми з вибіркової навчальної дисципліни «Основні технології виготовлення зубних протезів» відповідно до кредитно-трансферної системи організації навчального процесу. Сформульовано конкретні цілі вивчення дисципліни у вигляді певних професійних умінь до відповідних розділів. Відображено засоби діагностики рівня підготовки студентів та рекомендовано форми контролю за допомогою навчального посібника «Технологічні аспекти виготовлення ортопедичних конструкцій».

Ключові слова: навчальна дисципліна, навчальний процес, навчальний посібник.

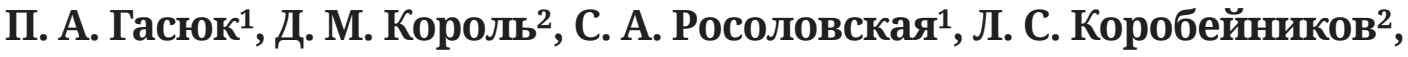 В. Б. Радчук ${ }^{1}$, Р. В. Козак ${ }^{2}$

ГВУЗ «Тернопольский государственный медицинский университет имени И. Я. Горбачевского» 1

ВГУЗ Украины «Украинская медицинская стоматологическая академия», г. Полтава ${ }^{2}$

\section{Методология внедрения учебного пособия «Технологические аспекты изготовления ортопедических конструкций» в учебный процесс с выборочной дисциплины}

Резюме. В статье изложена методика проектирования и разработки типичной программы по выборочной учебной дисциплине «Основные технологии изготовления зубных протезов» согласно кредитно-трансферной системы организации учебного процесса. Сформулированы конкретные цели изучения дисциплины в виде определенных профессиональных умений к соответствующим разделам. Отображены средства диагностики уровня подготовки студентов и рекомендуемые формы контроля с помощью учебного пособия «Технологические аспекты изготовления ортопедических конструкций».

Ключевые слова: учебная дисциплина, учебный процесс, учебное пособие. 


\section{P. A. Hasiuk ${ }^{1}$, D. M. Korol ${ }^{2}$, S. O. Rosolovska ${ }^{1}$, L. S. Korobeynikov², V. B. Radchuk ${ }^{1}$, R. V. Kozak ${ }^{2}$}

I. Horbachevsky Ternopil State Medical University ${ }^{1}$

HSEI of Ukraine «Ukrainian Medical Stomatological Academy», Poltava ${ }^{2}$

\section{Methodology of implementation of textbook «Technological aspects of the manufacture of prosthetic» in the education process with selective discipline}

Summary. The methods of development and elaboration of standard selective training discipline "The basic technologies of dentures construction" according to the European Credit Tranter System have been shown in the article. The specific objectives of discipline study in the form of particular professional skills required for corresponding thematic modules have been formulated. The means of students' preparation level evaluation and recommended control forms have been revealed with the help of the textbook "Technological aspects of the manufacture of orthopedic structures".

Key words: academic discipline, the learning process, textbook.

За наказом Міністерства охорони здоров’я України № 929 від 07.12. 2009 р. «Про затвердження та введення нового навчального плану підготовки фахівців освітньо-кваліфікаційного рівня "Спеціаліст» кваліфікації «Лікар-стоматолог» у вищих навчальних закладах IV рівня акредитації за спеціальністю «Стоматологія» стоматологічні факультети ВНЗ України перейшли на кредитно-модульну систему організації навчального процесу. Перехід до нової моделі навчання потребував від викладачів профільних стоматологічних кафедр оволодіння системою відповідних психолого-педагогічних та методичних вмінь. Дуже корисними виявилися знання, одержані ними ще у 2007 році під час навчання на ФПК при Національному медичному університеті імені О. О. Богомольця за програмою циклу «Вища медична освіта і Болонський процес» та на курсах підвищення кваліфікації викладачів протягом 2009-2011 років 3 циклу «Болонський процес, психологія та педагогіка вищої школи, сучасні інформаційні технології».

Серед дисциплін, які викладають на кафедрі ортопедичної стоматології дВНЗ «Тернопільський державний медичний університет імені І. Я. Горбачевського MO3 України» та кафедрі пропедевтики ортопедичної стоматології ВДНЗ України
«Українська медична стоматологічна академія» за новим навчальним планом передбаченовивченнястудентами ІІкурсу вибіркової дисципліни "Основні технології виготовлення зубних протезів", типова програма якої була відсутня. Використовуючи досвід викладання даної дисципліни за традиційною системою навчання, надбаних знань 3 організації кредитно-модульної системи організації навчального процесу $[2,8,9]$ та відповідно до наказу МО3 України «Про внесення змін та доповнень до Рекомендацій щодо розроблення навчальних програм» співробітники кафедри пропедевтики ортопедичної стоматології підготували програму навчальної дисципліни «Основні технології виготовлення зубних протезів», яку в жовтні 2011 року було розглянуто ЦМК з вищої медичної освіти Департаментом кадрової політики, освіти та науки і затверджено МО3 України [6, 7].

Головною метою вивчення вибіркової дисципліни «Основні технології виготовлення зубних протезів» $є$ ознайомлення студентів із сучасними видами незнімних та знімних ортопедичних конструкцій. Засвоєння цієї дисципліни закладає основи вивчення пропедевтики ортопедичної стоматологіїта ортопедичноїстоматології, передбачає інтеграцію викладання 3 цими дисциплінами та формування вмінь 
застосовувати надбані знання в процесі подальшого навчання й у професійній діяльності [1, 4].

На підставі кінцевих цілей дисципліни формулюються конкретні завдання щодо вивчення предмета у вигляді певних професійних умінь, які забезпечують досягнення мети. Певні цілі вивчення змістового модуля передбачають уміння студентів визначати показання та протипоказання до застосування вкладок, штучних коронок, штифтових конструкцій, мостоподібних протезів, часткових знімних пластинкових, повних знімних та бюгельних протезів; пояснювати технологічні особливості їх виготовлення; демонструвати на фантомах клініколабораторні етапи виготовлення незнімних та знімних конструкцій; аналізувати переваги та недоліки цих конструкцій та обірунтовувати вибір матеріалів для їх виготовлення $[3,10]$.

Зміст кожного розділу на підставі конкретних цілей поданий у вигляді переліку тем до практичних занять, самостійної роботи студентів, а також практичної підготовки з розділу.

Видами навчальних занять, згідно 3 навчальним планом, $€$ практичні заняття, які передбачають опанування студентами теоретичних основ технології виготовлення знімних та незнімних конструкцій зубних протезів у процесі вивчення фантомних мікростендів i комп’ютерного відеоматеріалу, вирішення ситуаційних тестових завдань, самостійна, індивідуальна робота студентів 3 обов'язковим веденням навчального посібника «Технологічні аспекти виготовлення ортопедичних конструкцій» для самостійної підготовки, в яких викладено зміст основних положень теми та завдання у вигляді малюнків і схем, підготовка до практичних занять, підготовка до контро-

\section{Список літератури}

1. Воробець А. Б. Матеріали підготовки до практичних занять $з$ предмету «Ортопедична стоматологія» / А. Б. Воробець, О. А. Беденюк. - Свідоцтво про реєстрацію авторського права на твір № 59011 від 25.03.2015.

2. Гасюк П. А. Альбом із пропедевтики ортопедичної стоматології : навч. посіб. - 2-ге видання / лю засвоєння розділів, підготовка огляду наукової літератури з тем, які виносяться та самостійне опрацювання та не входять до плану аудиторних занять [5].

Відсутність літератури, яка відповідала бзмістовінавчальноїпрограмивибіркової дисципліни «Основні технології виготовлення зубних протезів» для студентів другого курсу стоматологічного факультету, спонукала авторів до видання навчального посібника з курсу за вибором.

Автори посібника викладають короткий нарис із технології виготовлення вкладок та штифтових конструкцій, технології виготовлення штучних коронок, технології виготовлення штампованопаяного мостоподібного протеза, технології виготовлення металопластмасових та металокерамічних мостоподібних протезів, основних матеріалів для виготовлення незнімних конструкцій зубних протезів, технології виготовлення часткових та повних знімних протезів, технології виготовлення бюгельного протеза, основних матеріалів для виготовлення знімних конструкцій зубних протезів та допоміжних матеріалів для виготовлення зубних протезів [5].

Впровадження нової моделі організації навчального процесу - Європейської системи трансферних кредитів (ESTC), змінило методологію освітньо-професійної додипломної підготовки лікарів. Принциповою відмінністю такої системи проектування програми дисципліни «Основні технології виготовлення зубних протезів» стало структурування ii на розділи та введенням залікових кредитів як одиниці виміру навчального навантаження студента. Однак незважаючи на відсутність альтернативних тенденцій принципам Болонського процесу в цій програмі, вдалося адаптувати і зберегти роками напрацьовані власні досягнення.

П. А. Гасюк, В. В. Щерба. - Тернопіль : ТДМУ, Укрмедкнига, 2015. - 222 с.

3. Гасюк П. А. Альманах з ортопедичної стоматології / [П. А. Гасюк, Є. Я. Костенко, В. Р. Мачоган та ін.]. - Тернопіль : Богдан, - 2015. - 350 с.

4. Гасюк П. А. Матеріали підготовки до практичних занять 3 предмету «Ортопедична 
стоматологія» / П. А. Гасюк, С. О. Росоловська. Свідоцтво про реєстрацію авторського права на твір № 59027 від 25.03.2015.

5. Гасюк П. А. Технологічні аспекти виготовлення ортопедичних конструкцій / [П. А. Гасюк, Д. М. Гасюк, С. О. Росоловська та ін.]. - Тернопіль : ФОП Пархін Р. А., 2016. - 140 с.

6. Король М. Д. Проект пропедевтичного курсу до навчальної програми 3 ортопедичної стоматології за кредитно-модульною системою навчання / М. Д. Король, Л. С. Коробейніков // Український стоматологічний альманах. - 2006. № 1. - С. 45-48.

7. Король М. Д. Розробка програми з ортопедичної стоматології для вищих медичних закладів освіти України III-IV рівнів акредитації за кредитно-модульною системою відповідно до вимог Болонської декларації / М. Д. Король, Л. С. Коробейніков, І. М. Ткаченко // Самостійна робота студентів і кредитно-модульна система організації навчального процесу : матер. навч.метод. конф. - Полтава, 2007. - С. 90-93.

8. Удод А. А. Болонский процесс и стоматологическое образование в Украине: проблемы и перспективы / А. А. Удод, М. И. Косарева, М. Б. Первак // Вісник стоматології. - 2006. - № 1 (51). - С. 112-115.

9. Думанский Ю. В. О целесообразности кредитномодульной организации учебного процесса в системе высшего стоматологического образования / Ю. В. Думанский, А. Н. Талалаенко, А. А. Удод [та ін.]. // Український стоматологічний альманах. - 2011. - № 4. - С. 71-73.

10. Щерба В. В. Матеріали підготовки до практичних занять 3 предмету «Пропедевтика ортопедичної стоматології» / В. В. Щерба, С. О. Росоловська. - Свідоцтво про реєстрацію авторського права на твір № 59014 від 25.03.2015. 